\title{
PENERAPAN LANGUAGE EXPERIENCE APPROACH DALAM PEMBELAJARAN KETERAMPILAN BERBICARA
}

\author{
Tati Sri Uswati dan Itaristansi \\ IAIN Syekh Nurjati Cirebon \\ tatisriuswati@gmail.com
}

\begin{abstract}
Abstrak
Apabila seseorang memiliki keterampilan berbicara yang baik, dia akan memperoleh keuntungan sosial maupun profesional.Pada pelaksanaan pembelajaran bahasa Indonesia di sekolah, guru kurang mengajak siswa untuk lebih aktif menyimak, berbicara, membaca, dan menulis. Kondisi ini mengakibatkan kemampuan berbicara siswa menjadi rendah. Penelitian ini bertujuan untuk meningkatkan keterampilan berbicara pada kompetensi menceritakan kembali isi cerpen dengan menerapkan Language Experience Approach (LEA). Penelitian tindakan kelas (PTK) ini dilaksanakan di MAN 2 Kota Cirebon. Teknik pengumpulan data, meliputi: angket, observasi, wawancara, dan tes keterampilan bercerita. Hasil penelitian menunjukkan bahwa penerapan strategi LEA dapat meningkatkan keterampilan bercerita. Peningkatan tersebut ditunjukkan dari kualitas pembelajaran yang tercermin pada keaktifan, perhatian dan konsentrasi, minat selama pembelajaran, serta keberanian siswa bercerita di depan kelas.
\end{abstract}

Kata Kunci: keterampilan, bercerita, Language Experience Approach, berbahasa

\begin{abstract}
If a person has good speech skills, he or she will gain both social and professional benefits. In the implementation of Indonesian language learning in schools, teachers do not invite students to be more active in listening, speaking, reading and writing. This condition results in low student speaking ability. This study aims to improve speaking skills on the competence of retelling the contents of the short story by applying the Language Experience Approach (LEA). This class action research (PTK) is conducted in MAN 2 Kota Cirebon. Data collection techniques, including: questionnaires, observations, interviews, and skills test storytelling. The results showed that the implementation of LEA strategy can improve the storytelling skills. The improvement is reflected in the quality of learning reflected in liveliness, attention and concentration, interest during learning, and the courage of students telling stories in front of the class.
\end{abstract}

Keywords: skills, storytelling, Language Experience Approach, speaking

\section{A. Pendahuluan}

Keterampilan berbahasa meliputi empat aspek, yaitu menyimak atau mendengarkan, berbicara, membaca, dan menulis. Siswa harus menguasai keempat aspek tersebut agar terampil berbahasa. Dengan demikian, pembelajaran keterampilan 
berbahasa di sekolah tidak hanya menekankan pada teori saja, tetapi siswa dituntut untuk mampu menggunakan bahasa sebagaimana fungsinya, yaitu sebagai alat untuk berkomunikasi.

Salah satu aspek berbahasa yang harus dikuasai oleh siswa adalah berbicara, sebab keterampilan berbicara menunjang keterampilan lainnya (Tarigan, 1986:86). Keterampilan ini bukanlah suatu jenis keterampilan yang dapat diwariskan secara turun temurun walaupun pada dasarnya secara alamiah setiap manusia dapat berbicara. Namun, keterampilan berbicara secara formal memerlukan latihan dan pengarahan yang intensif. Stewart dan Kennert Zimmer (Haryadi dan Zamzani, 1997:56) memandang kebutuhan akan komunikasi yang efektif dianggap sebagai suatu yang esensial untuk mencapai keberhasilan setiap individu maupun kelompok. Siswa yang mempunyai keterampilan berbicara yang baik, pembicaraannya akan lebih mudah dipahami oleh penyimaknya. Berbicara menunjang keterampilan membaca dan menulis. Menulis dan berbicara mempunyai kesamaan yaitu sebagai kegiatan produksi bahasa dan bersifat menyampaikan informasi. Kemampuan siswa dalam berbicara juga akan bermanfaat dalam kegiatan menyimak dan memahami bacaan. Akan tetapi, masalah yang terjadi di lapangan adalah tidak semua siswa mempunyai kemampuan berbicara yang baik. Oleh sebab itu, pembinaan keterampilan berbicara harus dilakukan.

Pentingnya keterampilan berbicara atau bercerita dalam komunikasi juga diungkapkan oleh Supriyadi (2005: 178) bahwa apabila seseorang memiliki keterampilan berbicara yang baik, dia akan memperoleh keuntungan sosial maupun profesional. Keuntungan sosial berkaitan dengan kegiatan interaksi sosial antarindividu, sedangkan keuntungan profesional diperoleh sewaktu menggunakan bahasa untuk membuat pertanyaan-pertanyaan, menyampaikan fakta-fakta dan pengetahuan, menjelaskan dan mendeskripsikan. Keterampilan berbahasa lisan tersebut memudahkan siswa berkomunikasi dan mengungkapkan ide atau gagasan kepada orang lain.

Menurut pandangan whole language, berbicara tidak diajarkan sebagai suatu pokok bahasan yang berdiri sendiri, melainkan merupakan satu kesatuan dalam pembelajaran bahasa bersama dengan keterampilan berbahasa yang lain. Kenyataan tersebut dapat dilihat bahwa dalam proses pembelajaran bahasa, keterampilan berbahasa tertentu dapat dikaitkan dengan keterampilan berbahasa yang lain. Jadi pada proses 
pembelajaran, khususnya Bahasa Indonesia, keterampilan berbicara pada pokok bahasan tertentu dapat dikaitkan dengan aspek keterampilan menyimak, membaca, dan menulis.

Salah satu alternatif yang dapat dilakukan dalam pembelajaran keterampilan berbicara siswa sekolah adalah penerapan LEA dalam pembelajaran berbicara siswa. Seperti dikutip oleh Harjasujana (1997: 196-197) bahwa Huff mendefinisikan LEA berdasarkan makna yang terkandung dalam unsur-unsur kata pembentuknya, terutama kata experience dan language. Menurut Huff, experience merupakan pengalaman seseorang yang diperoleh dari aktivitas tertentu. Sementara itu, language merupakan cerminan dari empat aspek keterampilan berbahasa yang meliputi menyimak, berbicara, membaca, dan menulis. LEA dimaknai sebagai suatu pendekatan dalam pengajaran berbicara yang melibatkan kegiatan menyimak, berbicara, membaca, dan menulis sebagai cerminan dari pengalaman berbahasa anak.

Oka (dalam Harjasujana, 1997: 187) mengatakan bahwa pendekatan pengalaman berbahasa adalah metode pengajaran penguasaan keterampilan berbahasa yang menggabungkan pembelajaran berbicara dengan pengalaman bahasa anak yang meliputi menyimak, berbicara, membaca, dan menulis. Aspek yang harus diperhatikan dalam pembelajaran itu meliputi kemampuan berpikir dan kemampuan mengungkapkan bahasa.

Menurut Badudu (1993:131) pelaksanaan pembelajaran bahasa Indonesia dari jenjang Sekolah Dasar sampai Sekolah Menengah Atas masih terkesan bahwa guru terlalu banyak menyuapi materi, guru kurang mengajak siswa untuk lebih aktif menyimak, berbicara, membaca, dan menulis. Proses pembelajaran di kelas yang tidak relevan dengan yang diharapkan, mengakibatkan kemampuan berbicara siswa menjadi rendah. Pembelajaran berbicara pada peserta didik MA Negeri 2 Kota Cirebon menunjukkan hasil yang kurang memuaskan (masih kurang). Hal ini disebabkan oleh beberapa faktor yang memengaruhi, di antaranya belum diupayakan penggunaan pendekatan yang tepat agar siswa termotivasi untuk dapat berbicara/bercerita dengan baik dan lancar. Pendekatan pengalaman berbahasa (PPB) Menurut Space (Harjasujana, 1997:198) asumsi dasar penggunaannya adalah ekspresi bahasa lisan siswa yang didasarkan pada pikiran, perasaan, dan pengalamannya sendiri. Karena dieksplorasi berdasarkan pengalamannya sendiri, siswa akan lebih mudah mengungkapkannya. Oleh karena itu, diharapkan PPB ini mampu meningkatkan kualitas pembelajaran berbicara 
siswa, khususnya melalui keterampilan menceritakan kembali isi cerpen. Keterampilan menceritakan kembali adalah salah satu bentuk keterampilan berbicara. Sebagai salah satu bentuk keterampilan berbicara, keterampilan ini perlu dibina dan dikembangkan. Dengan demikian, penelitian yang bertujuan untuk meningkatan keterampilan berbicara (menceritakan kembali isi cerpen) dengan pendekatan pengalaman berbahasa perlu diujicobakan.

Berdasarkan latar belakang masalah di atas, rumusan permasalahan dalam penelitian ini adalah bagaimana peningkatan proses pembelajaran berbicara/bercerita dengan Language Experience Approach (LEA) atau pendekatan pengalaman berbahasa (PPB) pada siswa kelas XI MIA 3 MAN 2 Kota Cirebon dan bagaimana peningkatan keterampilan berbicara/bercerita dengan Language Experience Approach (LEA) atau pendekatan pengalaman berbahasa (PPB) pada siswa kelas XI MIA 3 MAN 2 Kota Cirebon. Dengan demikian, tujuan penelitian ini adalah untuk meningkatkan kualitas proses pembelajaran dan keterampilan berbicara/bercerita siswa kelas XI MIA 3 MAN 2 Kota Cirebon.

Penelitian ini diharapkan mampu memberikan kontribusi terhadap pembelajaran Bahasa Indonesia di Madrasah Aliyah. Hasil dari penelitian ini diharapkan dapat memberikan masukan terhadap guru-guru di Madrasah Aliyah dalam pelaksanaan pembelajaran keterampilan berbahasa siswa. Secara teoretis, penelitian ini diharapkan dapat memperkaya khazanah ilmu pengetahuan khususnya di bidang pembelajaran bahasa. Selain itu, diharapkan dapat menambah khazanah pustaka agar nantinya dapat digunakan sebagai penunjang kajian bahasa dan sastra dan dapat dijadikan sebagai bandingan yang sejenis. Manfaat praktisnya, bagi siswa, penelitian ini diharapkan dapat meningkatkan keterampilan berbahasa siswa dan dapat mengimplementasikannya dalam kehidupan sehari-hari. Bagi guru, hasil penelitian ini diharapkan dapat membuka wawasan guru dalam menerapkan pembelajaran keterampilan berbahasa khususnya keterampilan berbicara formal, sedangkan bagi peneliti lanjut, penelitian ini diharapkan dapat menjadi acuan dan referensi tambahan dalam pengkajian pembelajaran bahasa Indonesia di sekolah.

Kajian teori diuraikan pada penelitian ini, yaitu keterampilan berbicara, menceritakan kembali isi cerpen sebagai salah satu ragam kegiatan berbicara, karakteristik perkembangan remaja dan implikasinya pada pembelajaran 
keterampilan berbicara; Pendekatan Pengalaman Berbahasa (PPB) atau Language Experience Approach (LEA), serta PPB dalam Pembelajaran Berbicara (Menceritakan Kembali Isi Cerpen).

\section{B. Metode Penelitian}

Penelitian ini menggunakan rancangan Penelitian Tindakan Kelas untuk mencari pemecahan masalah kesulitan pembelajaran berbicara yang dialami oleh siswa MAN 2 Kota Cirebon kelas XI IPA3 semester ganjil, tahun pelajaran 2016/2017 pada Mata Pelajaran Bahasa Indonesia. Rangkaian model penelitian tindakan kelas ini adalah perencanaan (planning), tindakan (acting), observasi (observing), dan refleksi (reflecting), yaitu jenis Jenis penelitian tindakan kelas menurut Kemmis dan Mc. Tagart dalam Madya (2007: 59). Pertama, perencanaan berupa merencanakan pelaksanaan PPB dalam pembelajaran berbicara. Selanjutnya, menentukan langkah-langkah serta menyiapkan bahan pelajaran dan instrumen. Kedua, tindakan berupa: mengamati, menanya, menalar, dan mengomunikasikan. Pada tahap observasi yang dilakukan meliputi implementasi dalam pemantauan. Ketiga, observasi yang dilakukan adalah mengamati perilaku belajar siswa serta respons siswa terhadap penggunaan PPB, meliputi aspek keaktifan, perhatian dan konsentrasi, minat, antusias, dan keberanian siswa bercerita di depan kelas.

Hasil peningkatan skor ini adalah hasil dari bercerita (menceritakan kembali isi cerpen) dengan PPB melalui angket, lembar pengamatan, catatan lapangan, dan lembar penilaian keterampilan bercerita. Teknik analisis data menggunakan teknik statistik deskriptif, yaitu teknik statistik yang memberikan informasi mengenai data yang dimiliki dan tidak bermaksud menguji hipotesis, kemudian menarik inferensi yang digeneralisasikan untuk data yang lebih besar. Statistik deskriptif hanya dipergunakan untuk menyajikan dan menganalisis data agar lebih bermakna, komunikatif, dan disertai perhitungan sederhana yang bersifat memperjelas keadaan dan karakteristik data yang bersangkutan (Nurgiyantoro, 2009: 8).

\section{Hasil dan Pembahasan}

Hasil penelitian akan dipaparkan sesuai dengan kegiatan yang telah dilaksanakan, yaitu meliputi empat hal: perencanaan tindakan, pelaksanaan tindakan, observasi, dan 
refleksi. Keterampilan awal bercerita/menceritakan kembali isi cerpen siswa dilihat dari hasil penilaian tes bercerita sebelum dikenai tindakan.

\section{Tabel 1. Temuan Pratindakan}

\begin{tabular}{|c|c|}
\hline Aspek & Temuan \\
\hline Pelafalan & $\begin{array}{l}\text { banyak siswa yang melafalkan fonem kurang jelas } \\
\text { masih terpengaruh dialek Cirebon } \\
\text { suara siswa pun ketika bercerita kurang terdengar jelas } \\
\text { intonasi cukup baik tapi kurang bervariasi. }\end{array}$ \\
\hline Kosakata & $\begin{array}{l}\text { masih banyak siswa yang menggunakan istilah dan } \\
\text { ungkapan dalam bahasa daerah } \\
\text { menggunakan kata-kata hubung yang sama, misalnya } \\
\text { terus, lalu, dan pilihan kata kurang kaya. }\end{array}$ \\
\hline Struktur & struktur kalimatnya kadang kurang efektif \\
\hline Kesesuaian isi & alurnya tidak terkonsep dengan jelas dan datar \\
\hline Kelancaran & $\begin{array}{l}\text { masih dijumpai siswa yang berhenti bercerita karena } \\
\text { kurang hapal dengan ide pokok cerita } \\
\text { Jeda yang diucapkan kadang kurang tepat sehingga } \\
\text { makna dari kalimat yang diucapkan menjadi rancu }\end{array}$ \\
\hline Gaya & $\begin{array}{l}\text { masih banyak tertawa sendiri dan gesture kurang } \\
\text { menunjukkan ketepatan sesuai yang dikehendaki oleh } \\
\text { cerpen }\end{array}$ \\
\hline $\begin{array}{l}\text { Keterampilan mengolah } \\
\text { ide }\end{array}$ & $\begin{array}{l}\text { siswa masih belum optimal sehingga cerita menjadi } \\
\text { lebih sederhana dan menjadi sangat ringkas atau } \\
\text { pendek }\end{array}$ \\
\hline
\end{tabular}

Pengamatan pratindakan juga dilakukan terhadap keaktifan siswa dalam mengikuti belajar dalam tugas kerja kelompok. Hasilnya seperti berikut.

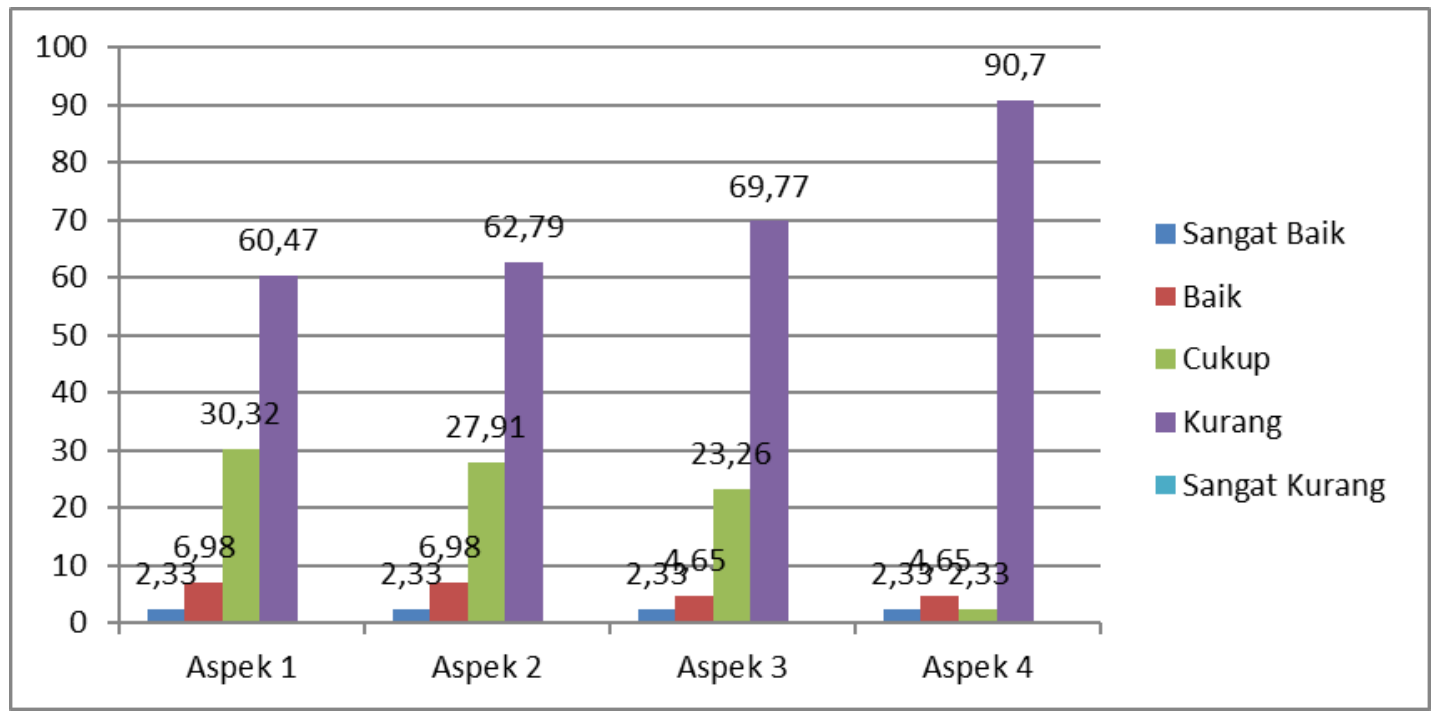

Gambar 1. Hasil Pengamatan Pembelajaran Menceritakan Kembali Isi Cerpen pada Tahap Pratindakan (dalam \%) 
Berdasarkan data dapat disimpulkan bahwa setiap aspek pengamatan proses belajar masuk kategori kurang. Hasil angket pratindakan menunjukkan bahwa: 1) siswa kurang mengetahui cara bercerita; 2) siswa kurang berminat dalam merangkai ide-ide pokok cerita cerpen menjadi sebuah cerita; 3) siswa kurang berperan, dan kurang antusias pada proses pembelajaran karena kurang menguasai materi berbicara/bercerita; serta 4) siswa menyatakan perlu adanya strategi/pendekatan tertentu yang memudahkan mereka untuk bercerita.

Kegiatan pada siklus pertama, meliputi: mengamati, menanya, mencoba, menalar, mengomunikasikan, dan merefleksi. Siswa membaca dan mencermati cerpen "Dia Teramat Malang" karya Asdina Ratnawati. Siswa melakukan tanya jawab dengan guru terkait dengan hasil pengamatannya. Siswa menyusun dan mengembangkan pokok-pokok cerita yang terdapat pada cerpen menjadi cerita yang menarik dan berkreasi. Siswa saling mengamati dan memberikan masukan kepada sesama anggota kelompoknya dalam berlatih bercerita. Siswa menceritakan kembali isi cerpen yang telah dibuatnya berdasarkan pengalaman hidup atau peristiwa yang pernah dialaminya di depan kelas. Siswa dan guru melakukan refleksi keberhasilan penceritaan siswa menggunakan LEA.

Adapun hasil refleksi menunjukkan bahwa pelaksanaan tindakan masih terdapat kekurangan dan belum menunjukkan hasil yang optimal. Hal ini dibuktikan dengan masih terdapat beberapa siswa yang kurang memahami pembelajaran, khususnya keterampilan bercerita menggunakan LEA. Kendala yang dihadapi pada siklus I, meliputi: 1) siswa kurang lancar dalam menceritakan kembali isi cerpen ke depan kelas, 2) kurang sesuainya isi cerita/urutan cerita, dan 3) gaya bercerita siswa masih kurang ekspresif. Permasalahan atau kendala-kendala yang terjadi pada siklus 1 akan menjadi dasar perbaikan di siklus II.

Siklus II melakukan aktivitas berupa: mengamati, menanya, mencoba, mengasosiasi atau menalar, dan mengomunikasikan. Siswa mencermati pengalaman hidup tokoh cerpen yang ditulis dan menceritakan kembali isinya. Siswa melakukan tanya jawab kembali dengan guru terkait dengan hasil pengamatannya. Guru memotivasi siswa serta menjelaskan aspek- aspek yang harus diperhatikan dalam menceritakan kembali. Siswa menyusun dan mengembangkan pokok-pokok cerita yang terdapat pada cerpen menjadi cerita yang menarik dan berkreasi. Siswa saling 
mengamati dan memberikan masukan kepada sesama anggota kelompoknya dalam berlatih bercerita. Siswa menceritakan kembali isi cerpen yang telah dibuatnya berdasarkan pengalaman hidup/ peristiwa yang pernah dialaminya. Siswa dan guru melakukan refleksi tentang hasil penceritaan siswa menggunakan LEA.

Hasil siklus II menunjukkan bahwa terdapat peningkatan pada setiap aspeknya. Hal ini ditunjukkan dengan hasil pengamatan keterampilan menceritakan kembali isi cerpen pada tahap siklus 1 masuk dalam kategori cukup, pada tahap siklus II ini semua aspek keterampilan berdiskusi masuk dalam kategori baik. Berikut ini perbandingan hasil siklus I dan siklus II.

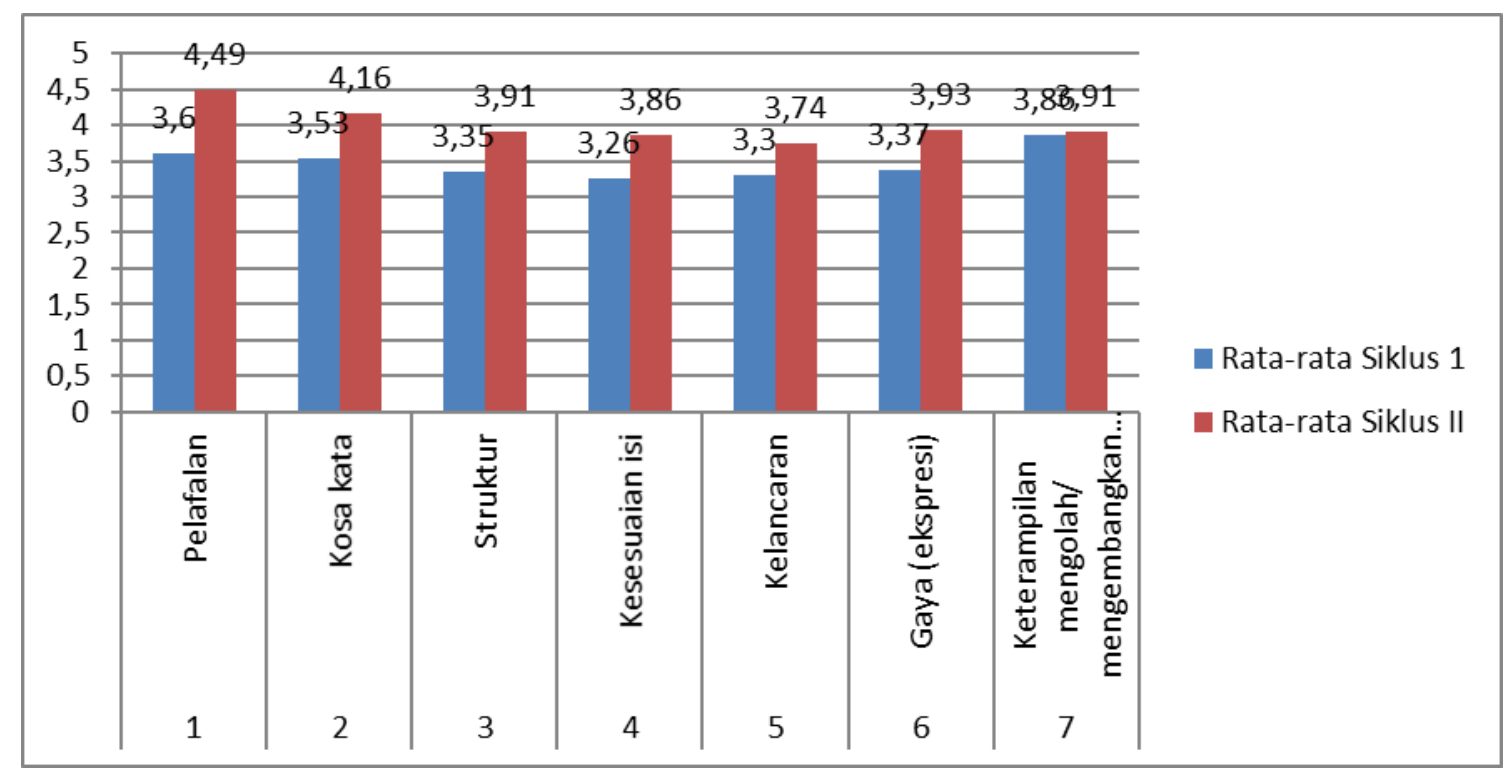

Gambar 2. Peningkatan Skor Keterampilan Bercerita dari Siklus I ke Siklus II

Keterampilan menceritakan kembali isi cerpen siswa termasuk dalam kategori baik. Hal tersebut menunjukkan adanya peningkatan dibandingkan siklus I. Pada siklus I keterampilan menceritakan kembali isi cerpen siswa secara proses masuk dalam kategori cukup. Semua aspek dalam pengamatan proses pada siklus II ini mengalami peningkatan. Siswa sudah semakin aktif, lebih berkonsentrasi dalam pembelajaran, berminat, dan lebih berani bercerita di depan kelas. Peningkatan keterampilan menceritakan kembali isi cerpen siswa dari tahap pratindakan ke siklus I, dan siklus II tampak seperti tabel berikut. 
Tabel 2.

Peningkatan Skor Rata-Rata Kelas Tiap Aspek dari Pratindakan, Siklus I, dan Siklus II

\begin{tabular}{llrrrc}
\hline No & \multicolumn{1}{c}{ Aspek } & \multicolumn{2}{c}{ Pratindakan Siklus I } & Siklus II & $\begin{array}{l}\text { Peningkatan dari } \\
\text { pratindakan } \\
\text { hingga siklus II }\end{array}$ \\
& & Rerata & Rerata & Rerata & \\
\hline 1 & Pelafalan & 2,63 & 3,60 & 4,49 & 1,86 \\
2 & Kosa kata & 2,56 & 3,53 & 4,16 & 1,60 \\
3 & Struktur & 2,58 & 3,35 & 3,91 & 1,33 \\
4 & Kesesuaian isi & 2,56 & 3,26 & 3,86 & 1,30 \\
5 & Kelancaran & 2,77 & 3,30 & 3,74 & 0,97 \\
6 & Gaya (ekspresi) & 2,56 & 3,37 & 3,93 & 1,37 \\
7 & Keterampilan & & & & 1,35 \\
& $\begin{array}{l}\text { mengolah/ } \\
\text { mengembangkan }\end{array}$ & 2,56 & 3,86 & 3,91 & \\
& ide pokok cerita & & & & $\mathbf{9 . 3 8}$ \\
\hline
\end{tabular}

Berikut ini peningkatan yang diperoleh siswa dengan menggunakan pembelajaran LEA. Aspek pelafalan mengalami peningkatan disebabkan oleh faktor penilaian pelafalan fon, fonem, suara, intonasi yang jelas pada hampir setiap siswa. Pelafalan siswa meningkat karena sebelumnya siswa berlatih saat pratindakan. Sebelum tindakan, siswa kurang berani berbicara. Pendekatan LEA memudahkan siswa berbicara dan bercerita karena cerita dieksplorasi dari pengalaman hidup sendiri. Kata-kata yang dilafalkan berarti rangkaian fonem yang dekat dan akrab dengan keseharian siswa sehingga dapat diucapkan dengan baik.

Aspek kosakata mengalami peningkatan yang ditandai dengan penggunaan katakata, istilah yang sesuai dengan tema dan karakter tokoh, terdapat variasi dalam pemilihan kata, dan lewat diskusi banyak kosakata yang keluar. Melalui LEA, siswa bercerita dengan lebih spontan dan pilihan kata yang komunikatif karena yang diceritakan karya sendiri sehingga penilaian pada aspek kosakata meningkat.

Peningkatan aspek struktur dibuktikan dengan banyaknya siswa yang sudah mampu menggunakan struktur kalimat dengan tepat. Adapun peningkatan pada aspek kesesuaiani isi dibuktikan dengan kesesuaian isi, tetapi tahapan alur yang disampaikan kurang terkonsep dengan jelas, isi cerita banyak yang kurang sesuai, kadang ada satu atau dua bagian alur yang hilang sehingga rangkaian cerita tidak lengkap. Siswa pada 
umumnya belum dapat merangkai-rangkaikan unsur cerita yang telah didiskusikan dalam bentuk cerita utuh yang disampaikan secara lisan.

Aspek kelancaran juga mengalami peningkatan. Hal ini dibuktikan dengan kemampuan siswa dalam berbicara/bercerita yang semula (tahap pratindakan) kurang lancar. Pada saat siklus I siswa mulai terbiasa dalam bercerita. Namun demikian, beberapa siswa terlihat gugup sehingga saat bercerita tersendat-sendat, jeda antarbagian cerita kadang lama. Peningkatan juga terjadi pada aspek gaya (ekspresi). Tampak sebagian besar siswa sudah tepat dalam mimik, gerak, dan suaranya, tetapi siswa yang mampu berimprovisasi terhadap gesture, suara, maupun mimik masih sedikit. Cukup banyak pula siswa yang masih grogi dalam bercerita.

Peningkatan juga terjadi pada aspek keterampilan mengolah/ mengembangkan ide pokok cerita. Hal ini terbukti pada pengembangan cerita yang cukup kreatif, sebagian besar tidak keluar dari tema (dia teramat malang), lukisan latar pada awal dan akhir cerita serta gambaran tokoh terkonsep jelas; amanat cerita cukup sesuai dengan tema, tetapi alur kurang terkonsep dengan jelas.

Pencapaian tindakan menggunakan LEA, baik dari aspek proses maupun aspek produk mengalami peningkatan dan perlu dipertahankan dan ditingkatkan. Pembelajaran bercerita yang telah dilakukan dengan menerapkan LEA menciptakan pembelajaran yang menyenangkan. Dengan adanya tugas kelompok berupa berdiskusi untuk berlatih bercerita dengan penentuan ide pokok cerita menjadikan siswa lebih terkonsentrasi dalam pembelajaran. Dengan adanya tugas yang diberikan oleh guru, siswa menjadi lebih mempunyai kesadaran untuk berpartisipasi memecahkan persoalan penentuan ide pokok cerita dan bagaimana menceritakannya.

Berdasarkan hasil wawancara dapat ditarik kesimpulan bahwa LEA dapat dijadikan salah satu alternatif untuk diterapkan dalam pembelajaran bercerita karena membuat siswa lebih berani berbicara (dalam hal ini bercerita). Dari hasil angket bercerita yang dibagikan kepada subjek penelitian dapat diketahui bahwa penggunaan LEA dapat meningkatkan keterampilan menceritakan kembali secara lisan isi cerpen. Hasil angket pernyataan minat dan antusias pembelajaran dengan LEA, menunjukkan bahwa dalam pembelajaran dengan PPB menumbuhkan minat dan antusias dalam bercerita. 


\section{Simpulan}

Setelah diberi tindakan menggunakan LEA, siswa lebih bersemangat dan lebih fokus pada pembelajaran bercerita. Pembelajaran menjadi lebih mudah dan menyenangkan. Hal ini disebabkan oleh ide yang diceritakan bersumber dari pengalaman hidup atau peristiwa yang dialami. Pembelajaran sudah tertib dan terarah sehingga guru dapat menjalankan tugasnya dengan baik dan efektif. Peningkatan juga dapat dilihat dari beberapa aspek, meliputi: 1) pelafalan, semua siswa sudah jelas pelafalan suara lantang intonasi baik, 2) kosakata, penggunaan ungkapan atau istilah siswa sudah baik atau tepat, 3) struktur, siswa sudah menggunakan struktur kalimat dengan baik, penjedaan baik sehingga makna kalimat tepat, 4) kesesuaian isi atau urutan cerita, siswa sudah bercerita dengan tahapan alur yang lengkap sehingga cerita mudah dipahami, 5) kelancaran, siswa sudah bercerita dengan runtut dan lancar, 6) gaya (ekspresi), siswa dalam bercerita sudah menggunakan mimik dan ekpsresi disertai dengan kinesik yang mendukung, bahkan ada improvisasi, serta 7) keterampilan mengolah/mengembangkan ide cerita berdasarkan pengalaman hidup/peristiwa yang pernah dialami, siswa dapat mengembangkan cerita yang sesuai dengan tema; alur, tokoh, dan latar terkonsep dengan jelas. Terdapat amanat cerita yang sesuai dengan tema.siswa pun sudah baik dalam penggunaan konjungsi sehingga cerita mengalir, menarik, dan dapat dipahami. Peningkatan secara produk dapat dilihat dari skor ratarata kelas yang diperoleh dari tahap pratindakan sampai siklus II.

\section{Daftar Pustaka}

Haryadi dan Zamzani.1996/1997. Peningkatan Keterampilan Berbahasa Indonesia. Depdikbud Dirjen Dikti bagian Proyek Pengembangan Pendidikan Guru Sekolah Dasar.

Nurgiyantoro, Burhan. 2009. Penilaian dalam Pengajaran Bahasa dan Sastra Indonesia. Yogyakarta: BPFE.

Undang-undang Republik Indonesia Nomor 20 tahun 2003 tentang Sistem Pendidikan Nasional. Jakarta: Departemen Pendidikan Nasional.

Supriyadi, dkk. 2005. Pendidikan Bahasa Indonesia 2. Jakarta: Depdikbud.

Tarigan, Djago. 1986. Pengembangan Keterampilan Berbicara. Jakarta:Depdikbud. 
Journal Indonesian Language Education and Literature Vol. 2, No. 2, 2017 http://www.syekhnurjati.ac.id/jurnal/index.php/jeill/

Supriyadi, dkk. 2005. Pendidikan Bahasa Indonesia 2. Jakarta: Depdikbud. 